University of Warwick institutional repository: http://go.warwick.ac.uk/wrap This paper is made available online in accordance with publisher policies. Please scroll down to view the document itself. Please refer to the repository record for this item and our policy information available from the repository home page for further information.

To see the final version of this paper please visit the publisher's website. Access to the published version may require a subscription.

Author(s): William H. Wilson, Glen A. Tarran, Declan Schroeder, Michael Cox, Joanne Oke and Gillian Malin

Article Title: Isolation of viruses responsible for the demise of an Emiliania huxleyi bloom in the English Channel

Year of publication: 2002

Link to published version:

http://dx.doi.org/10.1017/S0305004102005534

Publisher statement: None 


\title{
Isolation of viruses responsible for the demise of an Emiliania huxleyi bloom in the English Channel
}

\author{
William H. Wilson*§, Glen A. Tarran ${ }^{\dagger}$, Declan Schroeder*, Michael Cox ${ }^{\ddagger}$, \\ Joanne Oke* and Gillian Malin ${ }^{f}$ \\ * Marine Biological Association, Citadel Hill, Plymouth, PL1 2PB. 'Plymouth Marine Laboratory, Prospect Place, \\ Plymouth, PL1 3DH. ${ }^{\ddagger}$ Department of Biological Sciences, University of Warwick, Coventry, GV4 7AL. 'School of Environmental \\ Sciences, University of East Anglia, Norwich, NR4 7TJ. ${ }^{\S}$ Corresponding author, e-mail: whw@mba.ac.uk
}

This study used analytical flow cytometry (AFC) to monitor the abundance of phytoplankton, coccoliths, bacteria and viruses in a transect that crossed a high reflectance area in the western English Channel. The high reflectance area, observed by satellite, was caused by the demise of an Emiliania huxleyi bloom. Water samples were collected from depth profiles at four stations, one station outside and three stations inside the high reflectance area. Plots of transect data revealed very obvious differences between Station 1, outside, and Stations 2-4, inside the high reflectance area. Inside, concentrations of viruses were higher; E. huxleyi cells were lower; coccoliths were higher; bacteria were higher and virus:bacteria ratio was lower than at Station 1, outside the high reflectance area. This data can simply be interpreted as virusinduced lysis of $E$. huxleyi cells in the bloom causing large concentrations of coccoliths to detach, resulting in the high reflectance observed by satellite imagery. This interpretation was supported by the isolation of two viruses, EhV84 and EhV86, from the high reflectance area that lysed cultures of $E$. huxleyi host strain CCMP1516. Basic characterization revealed that they were lytic viruses approximately $170 \mathrm{~nm}-190 \mathrm{~nm}$ in diameter with an icosahedral symmetry. Taken together, transect and isolation data suggest that viruses were the major contributor to the demise of the E. huxleyi population in the high reflectance area. Close coupling between microalgae, bacteria and viruses contributed to a large organic carbon input. Consequent cycling influenced the succession of an E. huxleyi-dominated population to a more characteristic mixed summer phytoplankton community.

\section{INTRODUCTION}

Emiliania huxleyi (Haptophyta) is a unicellular alga found throughout the world's oceans. It is best known for its immense coastal and open ocean blooms at temperate latitudes that can cover $10,000 \mathrm{~km}^{2}$ or more. The size and intensity of these blooms makes E. huxleyi important for nutrient and $\mathrm{CO}_{2}$ cycling and biogenic sulphur production (in the form of dimethyl sulphide (Malin et al., 1994)) in the marine environment. Consequently it is a key species for current studies on global biogeochemical cycles and climate modelling (Charlson et al., 1987; Westbroek et al., 1993, 1994).

Emiliania huxleyi can be easily viewed by satellite imagery (Figure 1) (Holligan et al., 1993) since they are characterized by high light backscatter caused by coccoliths, elegant calcium carbonate scales, which E. huxleyi produces intracellularly and sequesters over its cell surface (Westbroek et al., 1984). Whilst E. huxleyi is blooming it is constantly producing and shedding coccoliths into the surrounding water. However, a bloom reveals itself most intensively on satellite images on its demise when the E. huxleyi cells in the bloom die and shed their remaining coccoliths. Subsequently, there is a vast export of coccoliths to the seabed (Ziveri et al., 2000), hence causing one of the largest long term sinks of inorganic carbon on earth.

One of the main mechanisms for the termination of E. huxleyi blooms is thought to be viral lysis. Several studies have shown that virus numbers typically increase following the demise of an E. huxleyi-dominated bloom (Bratbak et al., 1993, 1996; Brussaard et al., 1996; Castberg et al., 2001). It is clear from these investigations that viruses are intrinsically linked to the decline of E. huxleyi blooms. However, there have been no reports on the isolation of $E$. huxleyi-viruses, a necessary step in their characterization.

Viruses are abundant in aquatic environments (Bergh et al., 1989) and it is likely that most microbial organisms have viruses that infect them. Their contribution to nutrient (Wilhelm \& Suttle, 1999) and biogeochemical (Fuhrman, 1999) cycling, as well as their roles in influencing structure and diversity of microbial and phytoplankton communities are widely accepted (Fuhrman, 1999; Wommack \& Colwell, 2000). Viruses have also been observed to infect a wide range of aquatic algae (van Etten et al., 1991; van Etten \& Meints, 1999), including bloom forming marine phytoplankton (Nagasaki et al., 1994; Jacobsen et al., 1996; Nagasaki \& Yamaguchi, 1997; Sandaa et al., 2001).

In this paper we have used analytical flow cytometry to determine virus, bacteria, phytoplankton and coccolith concentrations through vertical profiles in a high reflectance area off the coast of Plymouth in the English Channel during July 1999. In addition, we describe the isolation of two E. huxleyi-viruses using seawater collected from this high reflectance area. 


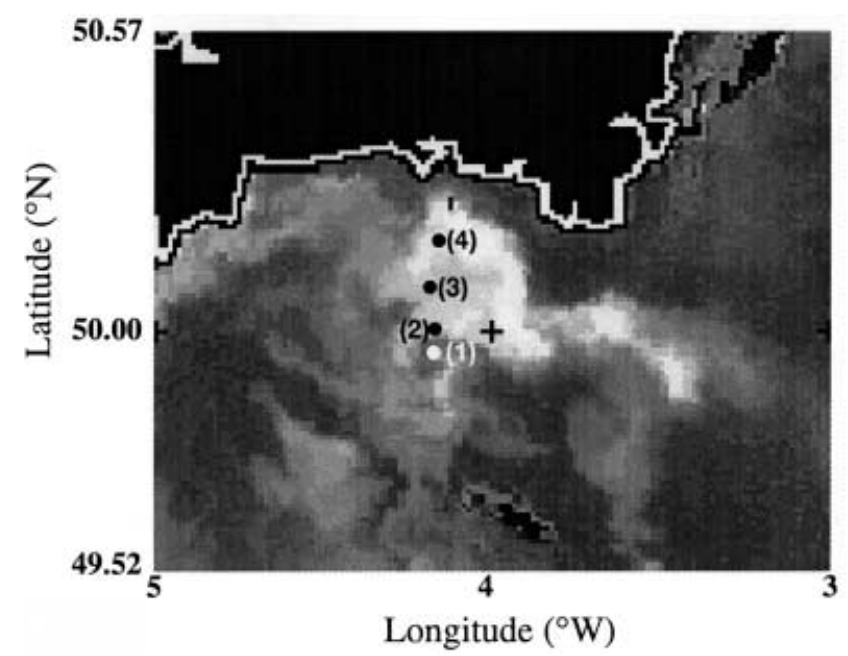

Figure 1. True colour satellite image of a high reflectance E. huxleyi bloom south of Plymouth, UK. Cruise track with approximate positions of Station 1 (white dot) and Stations $2-4$ (black dots); $49^{\circ} 57.98^{\prime} \mathrm{N} 4^{\circ} 10.00^{\prime} \mathrm{W}$ (Station 1$) ; 50^{\circ} 0.00^{\prime} \mathrm{N}$ $4^{\circ} 9.89^{\prime} \mathrm{W}$ (Station 2); $50^{\circ} 4.59^{\prime} \mathrm{N} 4^{\circ} 10.56^{\prime} \mathrm{W}$ (Station 3 ) and $50^{\circ} 13.79^{\prime} \mathrm{N} 4^{\circ} 9.59^{\prime} \mathrm{W}$ (Station 4 ). The cross in the middle of the figure (+) marks grid coordinate $50^{\circ} \mathrm{N} 4^{\circ} \mathrm{W}$. Image courtesy of Plymouth Marine Laboratory, UK, Remote Sensing Group.

\section{MATERIALS AND METHODS}

\section{Study sites}

The main study was conducted on the RV 'Squilla' on 30 July 1999 in an area of high reflectance associated with Emiliania huxleyi. The study area was located in the English Channel, off the South Devon/Cornwall coast (Figure 1). Samples were collected from four stations (Figure 1) along a northerly cruise transect with one station outside $49^{\circ} 57.98^{\prime} \mathrm{N} 4^{\circ} 10.00^{\prime} \mathrm{W}$ (Station 1) and three within the high reflectance area; $50^{\circ} 0.00^{\prime} \mathrm{N}$ $4^{\circ} 9.89^{\prime} \mathrm{W}$ (Station 2); $50^{\circ} 4.59^{\prime} \mathrm{N} 4^{\circ} 10.56^{\prime} \mathrm{W}$ (Station 3) and $50^{\circ} 13.79^{\prime} \mathrm{N} 4^{\circ} 9.59^{\prime} \mathrm{W}$ (Station 4). In addition, one depth profile was collected from Station L4 $\left(50^{\circ} 15^{\prime} \mathrm{N}\right.$ $\left.04^{\circ} 13^{\prime} \mathrm{W}\right)$, south of Plymouth, UK, in the English Channel on 26 July 1999.

\section{Sample collection}

Seawater was collected from a depth profile down to $25 \mathrm{~m}$, in $5 \mathrm{~m}$ intervals, using a rosette of 5-1 Niskin bottles connected to a stainless steel cable operated by an on-deck winch. For each depth, a $1.5 \mathrm{ml}$ aliquot of seawater was fixed in $0.5 \%$ (final concentration) glutaraldehyde for between $2 \mathrm{~h}$ and $7 \mathrm{~h}$ at $4{ }^{\circ} \mathrm{C}$ for subsequent virus and bacteria enumeration. Samples were then stored frozen at $-20^{\circ} \mathrm{C}$ until analysis one week after sampling. Samples for E. huxleyi and coccolith enumeration were collected from the rosette bottle sampler in sterile BlueMax ${ }^{\mathrm{TM}} 50-\mathrm{ml}$ polypropylene conical centrifuge tubes (Becton Dickinson Labware, Franklin Lakes, USA) and maintained in the dark at ambient seawater temperature in covered flow-through tanks. Samples were returned to the laboratory and analysed immediately. Samples for transmission electron microscopy (TEM) $(20 \mathrm{ml})$ were preserved in $2 \%$ glutaraldehyde then stored at $4^{\circ} \mathrm{C}$ until further analysis. Samples for virus isolation were pre-filtered through a $0.45 \mu \mathrm{m}$ Supor (Gelman) filter and stored at $4^{\circ} \mathrm{C}$ in the dark.

\section{Analytical flow cytometry $(A F C)$ analysis}

All analyses were conducted using a Becton Dickinson FACSort ${ }^{\mathrm{TM}}$ flow cytometer equipped with an air-cooled $15 \mathrm{~mW}$ laser providing $488 \mathrm{~nm}$ light with a standard filter set-up which measured chlorophyll fluorescence ( $>650 \mathrm{~nm})$, phycoerythrin fluorescence $(585 \mathrm{~nm} \pm 21 \mathrm{~nm})$, forward scatter (light scattered in the same plane as the laser beam) and side scatter (light scattered at ninety degrees to the plane of the vertically polarized laser). Virus and bacteria enumeration was performed on each sample at the same time using methods adapted from Marie et al. (1999). Fixed frozen samples were defrosted at room temperature and diluted ten-fold in TE buffer $(10 \mathrm{mM}$ Tris-HCl pH 7.5, $1 \mathrm{mM}$ EDTA) (pre-filtered through a $50 \mathrm{kDa}$ VivaFlow 50 'flip-flow' system (Sartorius) then autoclaved) containing $0.1 \%(\mathrm{w} / \mathrm{v})$ Triton X-100. Diluted samples were heated at $65^{\circ} \mathrm{C}$ for $15 \mathrm{~min}$ in the dark in the presence of SYBR Green I (Molecular Probes) at a final concentration of $10^{-4}$ of the commercial stock solution. Samples were analysed by AFG for two min at a flow rate of $12 \mu \mathrm{lmin}^{-1}$. Data acquisition was triggered on green fluorescence and the detection threshold was adjusted to cut out most of the instrument noise from the blank. Viruses in E. huxleyi lysates were prepared as for seawater, with the exception that lysates were diluted 1000 -fold prior to analysis. To prepare the blank, $10 \mathrm{kDa}$-filtered seawater was diluted ten-fold with TE buffer containing $0.1 \%$ Triton X-100 and SYBR Green I prior to AFC analysis. Measurements of side scatter and green fluorescence were made using CELLQuest ${ }^{\mathrm{TM}}$ software (Becton Dickinson) with $\log$ amplification on a four-decade scale. Data analysis was carried out using WinMDI 2.8 software (Joseph Trotter-freely available from http://facs.scripps.edu/). Scatter-plots of side-scatter vs green fluorescence were used to discriminate between different virus groups and bacteria. Large viruses could be easily discriminated from small viruses since there was at least an order of magnitude difference in their side scatter values (Wilson et al., in press).

Emiliania huxleyi and detached coccoliths were analysed separately by AFG using the same instrument as above. Data acquisition for E. huxleyi was triggered on chlorophyll fluorescence, using laboratory cultures to set rejection gates for background noise. Data acquisition for detached coccoliths was triggered on side scatter. Samples were analysed for three min at a flow rate of $91( \pm 1) \mu 1 \mathrm{~min}^{-1}$ and data was stored in listmode format then read using WinMDI 2.8 as above. Scatter-plots of side scatter vs chlorophyll fluorescence were produced for coccolithophores, and side scatter vs forward scatter for detached coccoliths. The scatter plots were also used to obtain particle counts for four other groups of phytoplankton (autotrophic dinoflagellates $(<50 \mu \mathrm{m})$, cryptophytes, other nanophytoplankton and picoeukaryotes).

\section{Transmission electron microscope analysis}

Gluteraldehyde-preserved samples were examined by TEM following ultracentrifugation of the particles directly onto formvar-coated copper grids (Børsheim et al., 1990). Centrifuge tubes were modified by moulding a flat supporting bottom of two-component epoxy glue (slow 
setting Araldite ${ }^{\mathbb{R}}$ ) by centrifuging the glue onto the bottom of the tube then leaving it to set. Modified centrifuge tubes were filled with preserved water and formvar-coated grids attached to nitro-cellulose filter paper were submersed below the surface and left to sink with the copper grids upwards. The samples were centrifuged in a Beckman L8$70 \mathrm{M}$ ultracentrifuge using a swing-out SW40 rotor at $30,000 \mathrm{rpm}(160,000 \mathrm{~g})$ for $1 \mathrm{~h}$ at $10^{\circ} \mathrm{C}$. Following centrifugation, the supernatant was poured off and the grid was airdried. For examination of viruses from lysed cultures, a drop of lysate was added to a formvar-coated grid and left for approximately $30 \mathrm{~min}$. Excess liquid was then wicked off and left to air dry. All grids were post-stained with a saturated solution (approximately $3 \% \mathrm{w} / \mathrm{v}$ ) of uranyl acetate. TEM analysis was conducted on a JEOL JEM 200CX TEM operated at $160 \mathrm{kV}$ at magnifications ranging from $\times 20,000$ to $\times 100,000$.

\section{Scanning electron microscope (SEM) analysis}

To view viruses attached to host $E$. huxleyi strain CCMP1516 cells, virus/host suspensions were fixed in 5\% glutaraldehyde, sedimented by centrifugation, dehydrated in an acetone series and critical point dried using acetone in a Polaron 3000 apparatus. Dried infected cells were shaken onto double-sided sticky tape on a specimen support stub. Specimens were sputter-coated with gold in an EMscope coating unit. Viruses attached to cells were viewed in a JEOL JSM 35C scanning electron microscope operated at $20 \mathrm{kV}$.

\section{Virus isolation and plaque purification}

Virus lysates were obtained by adding $1 \mathrm{ml}$ of $0.45 \mu \mathrm{m}$ filtered seawater, collected from a range of depths from Station $4 \quad\left(50^{\circ} 13.79^{\prime} \mathrm{N} \quad 4^{\circ} 9.59^{\prime} \mathrm{W}\right)$, to exponentially growing host $E$. huxleyi strain CCMP1516 (http://ccmp. bigelow.org/) in $\mathrm{f} / 2$ medium (Guillard, 1975). Once clearing of the host culture was observed, the lysate was passed through a $0.2 \mu \mathrm{m}$ syringe filter (Gelman). A virus clone was obtained by serial dilution to extinction three times. The highest dilution to lyse the host culture was passed through a $0.2 \mu \mathrm{m}$ syringe filter (Gelman) for use in subsequent inoculations.

The dilution to extinction virus lysate was further purified by three-rounds of a plaque purification assay. Serial dilutions $(100 \mu \mathrm{l})$ of the lysate were added to $0.9 \mathrm{ml}$ of a $100 \times$ concentration of exponentially growing $E$. huxleyi cells and incubated at $15^{\circ} \mathrm{C}$ under constant illumination for two hours to allow viruses to adsorb. The virus-host suspension was mixed in $3 \mathrm{ml}$ of molten $0.4 \%(\mathrm{w} / \mathrm{v})$ electrophoresis grade agar $\left(40^{\circ} \mathrm{C}\right)$, made in $\mathrm{f} / 2$ medium, and poured onto $1.5 \%(\mathrm{w} / \mathrm{v})$ electrophoresis grade agarose plates made in $\mathrm{f} / 2$ medium. Plaques were usually visible after four-days incubation at $15^{\circ} \mathrm{C}$ in a cooled illuminated incubator (Sanyo) set on a 16:8 h L:D cycle. A 1-mm diameter plug containing a single plaque was lifted from the plate using a sterile Pasteur pipette, resuspended in $0.5 \mathrm{ml} \mathrm{f} / 2$ medium and used for subsequent inoculations. Virus stocks (either fresh $0.2 \mu \mathrm{m}$-filtered lysates or plaque resuspensions) were stored at $4^{\circ} \mathrm{C}$ in the dark.

Infection kinetics of virus clones were determined by adding dilutions of the virus to exponentially growing
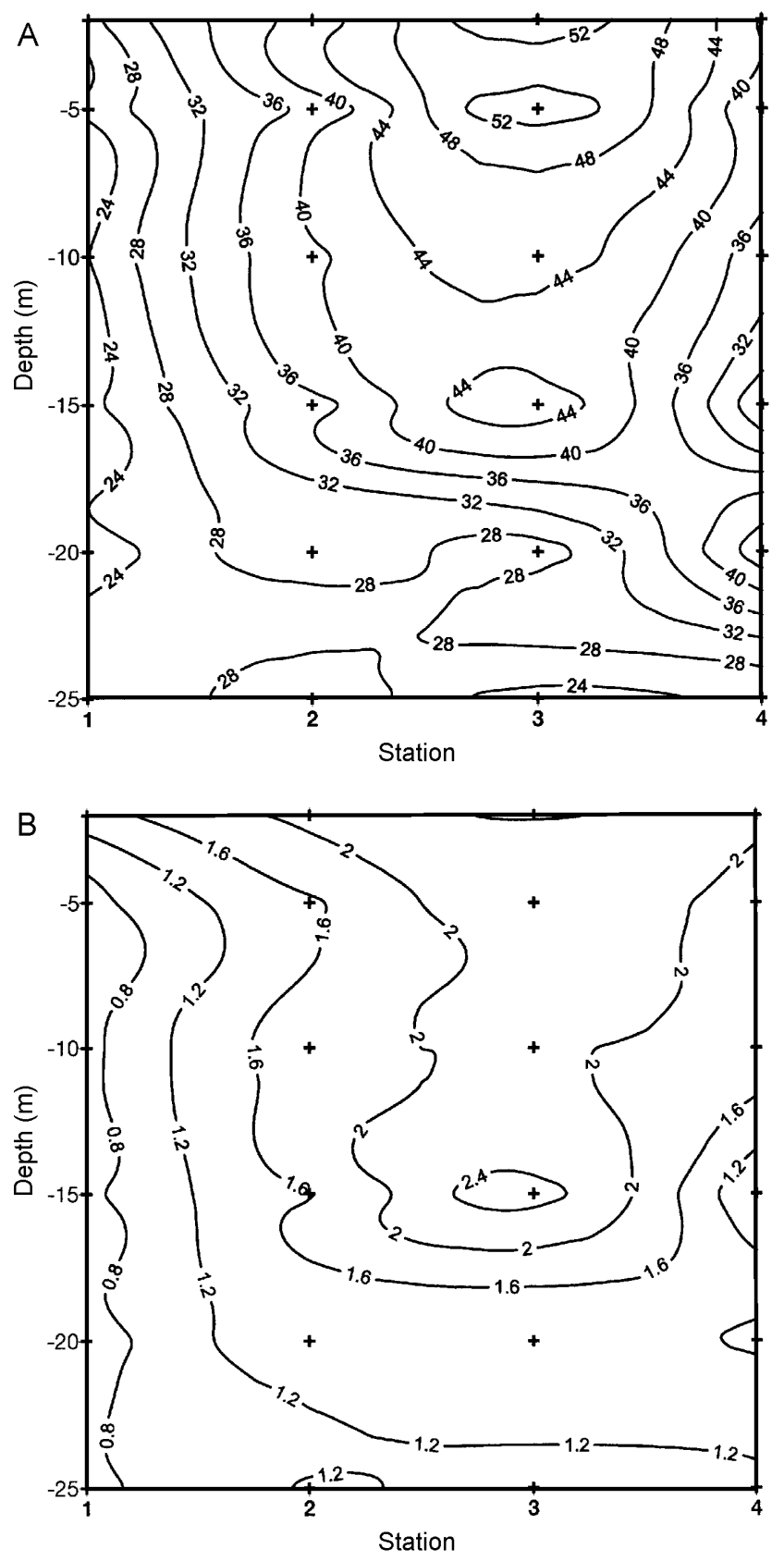

Figure 2. Contour plots of virus concentrations through the water column from Stations 1-4 on the cruise transect, determined by AFC. (A) Total virus $\left(\times 10^{6}\right.$ virus particles $\left.\mathrm{ml}^{-1}\right)$; and (B) large virus $\left(\times 10^{6}\right.$ virus particles $\left.\mathrm{ml}^{-1}\right)$ concentrations. Crosses indicate the depth at which samples were collected.

E. huxleyi strain CGMP1516 host cultures and following their growth compared to non-infected controls. E. huxleyi in the cultures were enumerated in a Neubauer improved haemocytometer.

\section{RESULTS}

Transect data

The high reflectance area was milky in appearance. The $32 \mathrm{~km}$ transect started at Station 1 just south of the high reflectance area, approximately $48 \mathrm{~km}$ south of Plymouth, UK, where the milky appearance of the surface water was less apparent. Surface chlorophyll concentrations inferred 

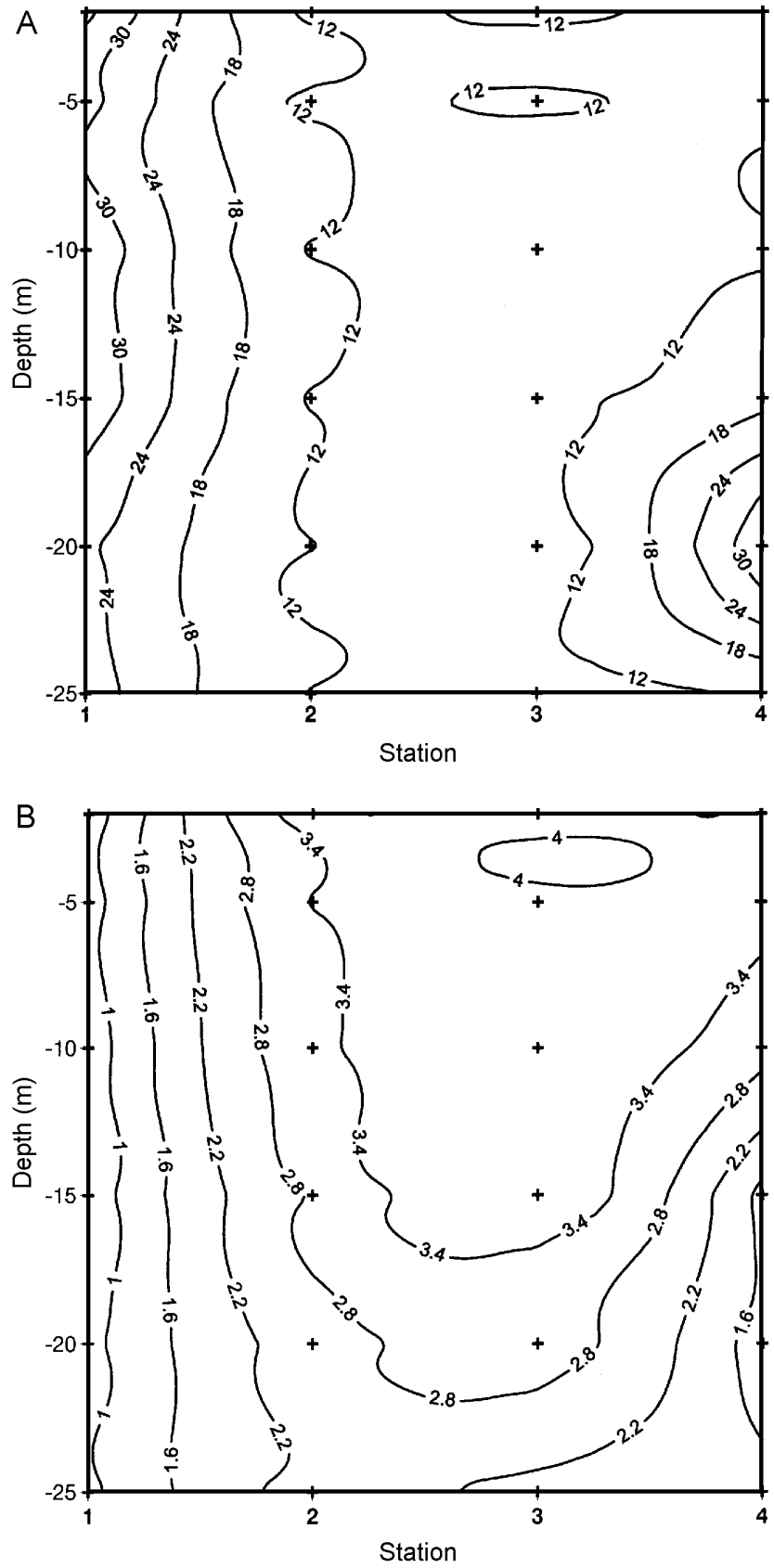

Figure 3. (A) Contour plots of virus:bacteria ratios and (B) bacteria concentrations $\left(\times 10^{6} \mathrm{cells} \mathrm{ml}^{-1}\right)$ through the water column determined by $\mathrm{AFC}$, from Stations $1-4$ on the cruise transect. Crosses indicate the depth at which samples were collected.

from satellite imagery ranged from $1.4 \mu \mathrm{g} \mathrm{l}^{-1}$ at Station 1 to $2-7.5 \mu \mathrm{g} \mathrm{l}^{-1}$ at Stations 2-4 (data not shown). Details of the physical structure of the bloom will be described elsewhere (T. Smyth, personal communication). Briefly, Station 1 had a deep mixed layer $(>30 \mathrm{~m})$ compared to Stations 2-4 which had a thermocline at approximately $25 \mathrm{~m}$. In addition, the surface water temperature increased by approximately $1^{\circ} \mathrm{C}$ towards the northern end of the transect.

Total virus concentrations ranged from $2.1 \times 10^{7} \mathrm{ml}^{-1}$ to $5.5 \times 10^{7} \mathrm{ml}^{-1}$ with the lowest concentrations (2.1$2.7 \times 10^{7} \mathrm{ml}^{-1}$ ) being observed at Station 1 (Figure 2A). A similar pattern was observed for large-virus-like particles (LVLP), with concentrations ranging from 5.6 to
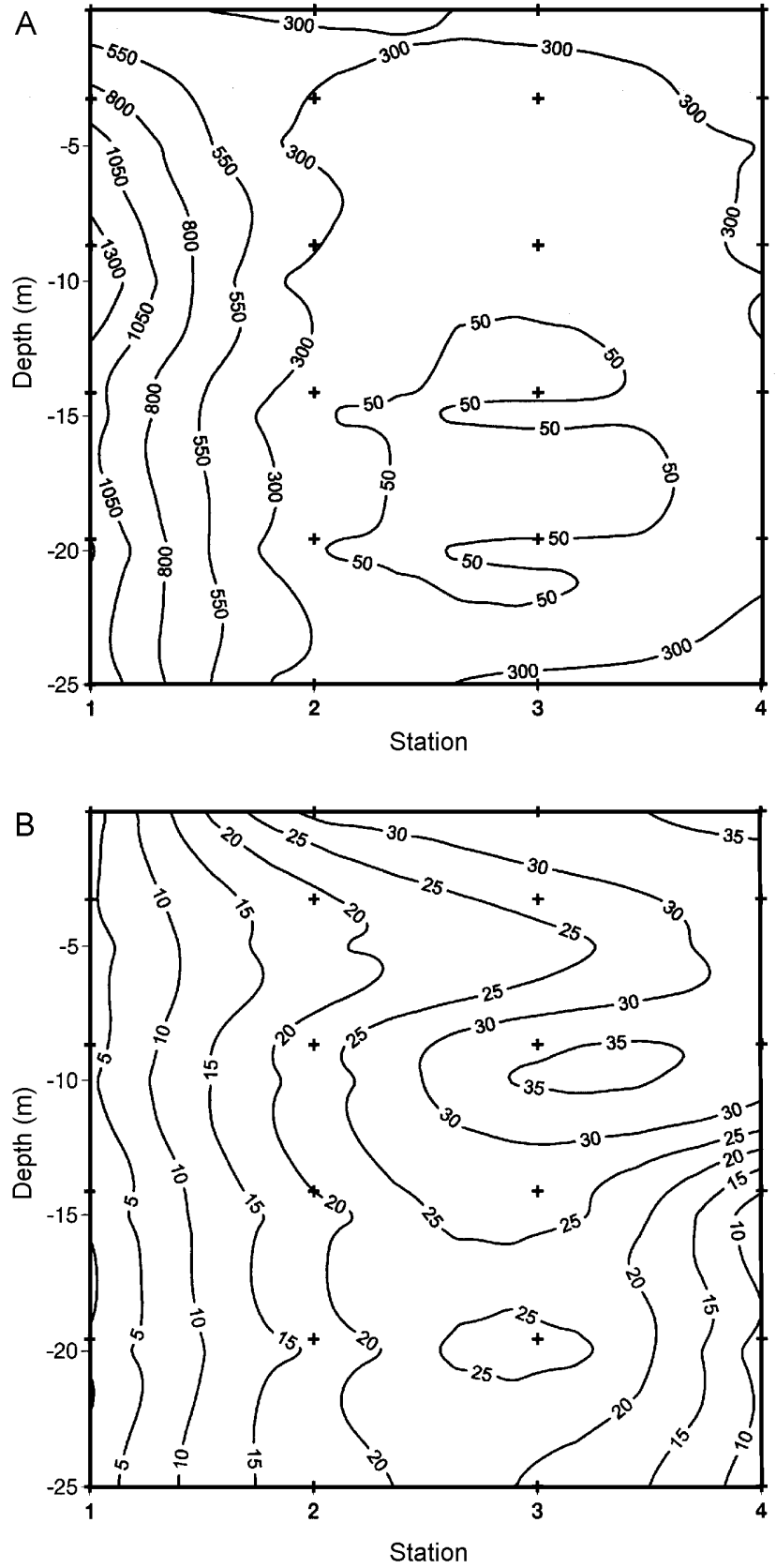

Figure 4. (A) Contour plots of E. huxleyi (cells ml ${ }^{-1}$ ) and (B) coccolith $\left(\times 10^{4}\right.$ liths $\left.\mathrm{ml}^{-1}\right)$ concentrations through the water column determined by AFC, from Stations $1-4$ on the cruise transect. Crosses indicate the depth at which samples were collected.

$14.0 \times 10^{5} \mathrm{ml}^{-1}$ at Station 1, increasing to 8.0 to $25.4 \times 10^{5} \mathrm{ml}^{-1}$ inside the high reflectance area (Figure 2B). At Stations 2-4 virus concentrations were higher in the surface layers and the highest concentrations were observed at Station 3. There was a large difference in virus to bacteria ratios between Station 1, which averaged 33.0 ( \pm 5.2$)$ through the water column, and Stations 2-4, which averaged $13.9( \pm 5.9)$ (Figure 3A). Bacteria concentrations were also high inside the high reflectance area $\left(1.3-4.0 \times 10^{6} \mathrm{ml}^{-1}\right)$ compared to Station $1(6.4-$ $8.6 \times 10^{5} \mathrm{ml}^{-1}$ ) (Figure 3B).

Emiliania huxleyi concentrations were highest at Station 1 ranging from 390 to 1500 cells $\mathrm{ml}^{-1}$ with increasing depth. 

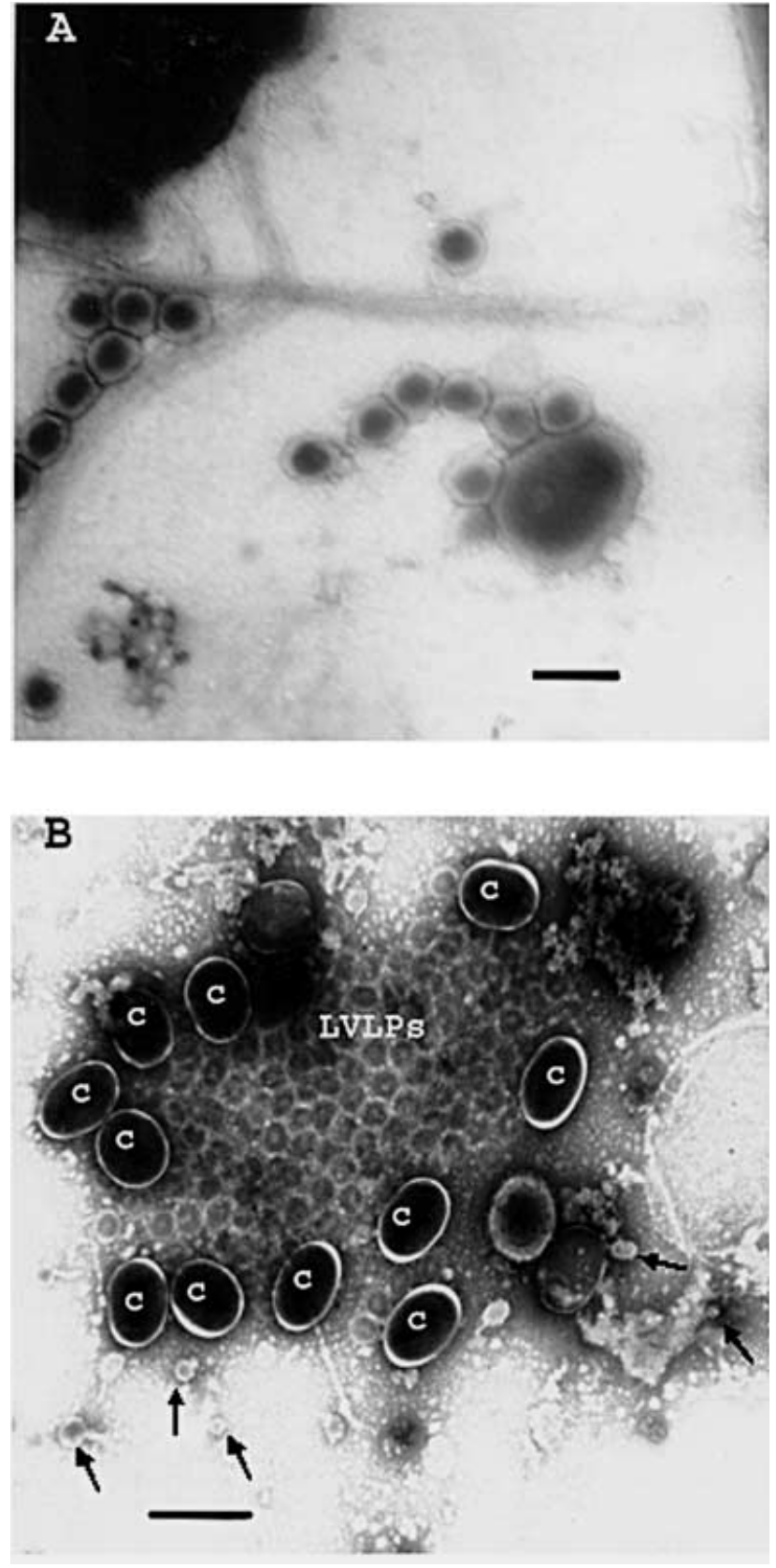

Figure 5. Transmission electron microscope analysis of fixed seawater samples collected from Station $4\left(50^{\circ} 13.79^{\prime} \mathrm{N}\right.$ $4^{\circ} 9.59^{\prime} \mathrm{W}$ ) of the cruise transect. (A) Numerous large virus-like particles (LVLP) approx $150 \mathrm{~nm}-200 \mathrm{~nm}$ in size were observed. (B) Large VLPs bursting from what we assumed was an Emiliania huxleyi cell surrounded by coccoliths (c). Small arrows indicate smaller VLPs that were also abundant in all water samples. Scale bars: A, $\sim 250 \mathrm{~nm} ; \mathrm{B}, \sim 500 \mathrm{~nm}$.

However, these concentrations dropped significantly inside the high reflectance area, ranging from less than

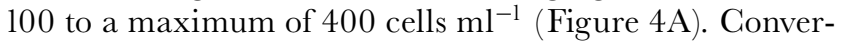
sely, detached coccolith concentrations were low outside the bloom in Station $1\left(1-3 \times 10^{4}\right.$ coccoliths $\left.\mathrm{ml}^{-1}\right)$ and an order of magnitude higher inside the bloom $\left(0.7-4 \times 10^{5}\right.$ coccoliths $\mathrm{ml}^{-1}$ ) (Figure 4B). Emiliania huxleyi dominated the phytoplankton community outside the high reflectance area at Station 1. Their numerical abundance was on average $48 \%( \pm 13 \%)$ of the total phytoplankton community through the water column, compared to an average of

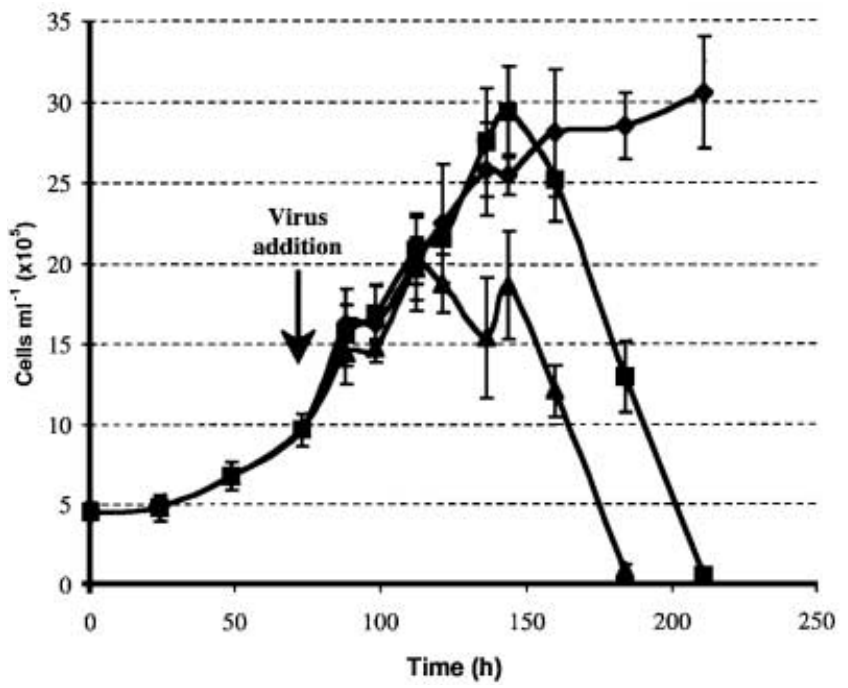

Figure 6. Infection kinetics of EhV86 propagated on Emiliania huxleyi strain CCMP1516 at multiplicity of infections of approximately $0.1(\boldsymbol{\Delta})$ and $0.001(\mathbf{\square})$ compared to a noninfected control

$7.8 \%( \pm 7.7 \%)$ at Stations 2-4. Other phytoplankton determined by AFG included autotrophic dinoflagellates $(<50 \mu \mathrm{m})$, other nanophytoplankton, cryptophytes and picoeukaryotes, whose concentrations all increased between Station 1 and Stations 2-4 inside the high reflectance area (data not shown).

Transmission electron microscope analysis of preserved samples collected from all stations revealed there was a large morphological diversity of virus like particles (VLPs) present. The most abundant VLPs were in the $40 \mathrm{~nm}-100$ nm size range (see arrows in Figure 5B). In addition, there was a higher number of larger particles in the $120 \mathrm{~nm}-$ $200 \mathrm{~nm}$ size range (Figure 5A), consistent with the high concentrations observed by AFG (Figure 2B). In some fields of view LVLPs were observed bursting from $E$. huxleyi cells, since they were surrounded by what appeared to be oval shaped coccoliths (Figure 5B). In each of these images between 120 and 150 LVLPs were associated with each E. huxleyi cell, however, on closer inspection it looked as if there was more than one layer of LVLPs, suggesting burst sizes $>300$.

\section{Virus isolation}

Seawater samples from all depths caused lysis of E. huxleyi strain CGMP1516 host cultures within ten days. Lysis was evident when the culture turned from a normal healthy milky-green colour to a milky white colour. In addition, a characteristic sulphurous odour was also indicative of culture lysis. Serial dilutions of these lysed cultures down to $10^{-7} \mathrm{ml}^{-1}$ lysed fresh exponentially growing $E$. huxleyi strain CGMP1516 host cultures, which indicated that lysed cultures contained at least $10^{7}$ infectious virus particles $\mathrm{ml}^{-1}$. Two clonal isolates were identified by dilution to extinction assays; EhV84, which was originally isolated from a seawater sample collected at a depth of $15 \mathrm{~m}$ from Station L4 $\left(50^{\circ} 15^{\prime} \mathrm{N} 04^{\circ} 13^{\prime} \mathrm{W}\right)$ on 26 July 1999 ; and $E$ W 86, which was originally isolated from a seawater sample collected at a depth of $15 \mathrm{~m}$ from Station 4 of the transect $\left(50^{\circ} 13.79^{\prime} \mathrm{N} 4^{\circ} 9.59^{\prime} \mathrm{W}\right)$ on 30 July 1999. Complete 

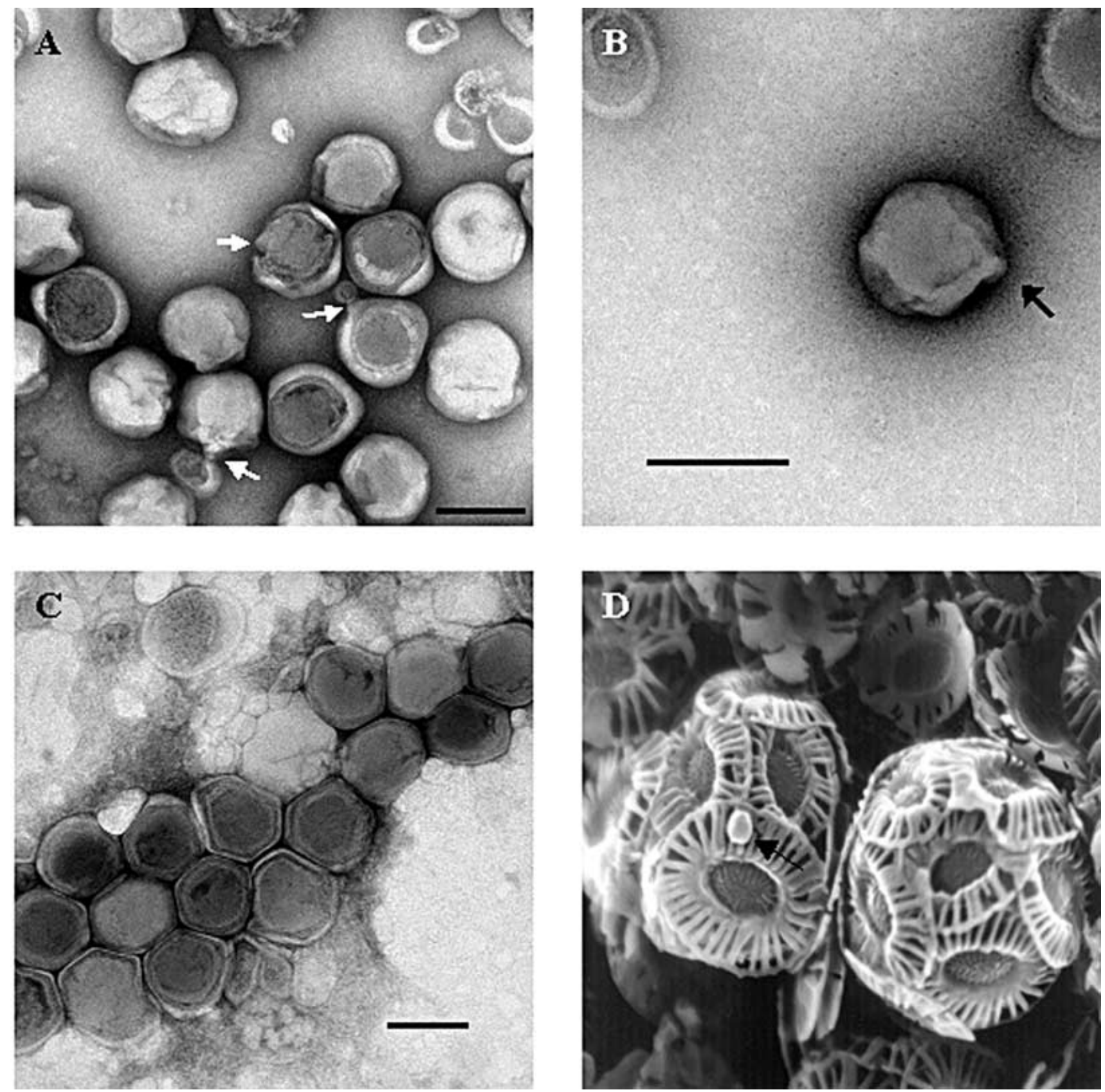

Figure 7. Transmission electron microscope (TEM) and scanning electron microscope (SEM) analysis of Emiliania huxleyi-specific virus isolates. (A) and (B) TEMs of EhV84, the arrows indicate possible tail stubs that may be involved in attachment. (C) TEM of EhV86. (D) SEM of EhV86 (arrowed) attached to an E. huxleyi cell. Scale bars: A-C, 190 nm; D, no scale information available.

lysis of E. huxleyi strain CGMP1516 host cultures by EhV 86 was observed four days (multiplicity of infection (MOI) 0.1 ) or five days (MOI 0.001) after virus addition (Figure 6). The TEM analysis of EhV84 and EhV86 revealed they were morphologically similar, icosahedral particles with diameters of $191 \mathrm{~nm}( \pm 13 \mathrm{~nm})($ EhV84) (Figure 7A,B) and $170 \mathrm{~nm}( \pm 17 \mathrm{~nm})($ EhV 86) (Figure $7 \mathrm{C})$. On some VLPs a small tail stub was visible (arrowed in Figure 7A,B) indicating a potential attachment mechanism. The SEM analysis of an $E \hbar \mathrm{V} /$ host suspension revealed several images of VLPs of the correct approximate size attached to the surface of an E. huxleyi cell (Figure 7D). However, it cannot be ruled out that these particles were binding to the surface of the E. huxleyi cells non-specifically.

Visual inspection of the plates during the plaque purification procedure revealed that $E$. huxleyi grew uninhibited in the plates, looking almost clear on day one to dark green after 2-3 weeks. Circular plaques approximately $1 \mathrm{~mm}$ diameter were observed after 4-d incubation (results not shown) for both EhV84 and EhV86. The size of the plaques gradually increased to approximately $8 \mathrm{~mm}$ diameter after 2-3 weeks incubation or when the cells 
stopped growing on the agar plate. A $1 \mathrm{~mm}$ plaque was shown to contain approximately $10^{4}$ plaque forming units (pfu) following further propagation.

\section{DISGUSSION}

The occurrence of a high reflectance bloom in the English Channel (Figure 1), only a few kilometres from our laboratory, presented an ideal opportunity to determine if viruses were involved in its dying stages. The high reflectance of such blooms, which allows them to be visualized by satellite imagery, is caused by backscattering of light by coccoliths detached from the Emiliania huxleyi cells (Gordon \& Du, 2001). Goccoliths form an elaborate shell around the cells. They are produced intracellularly in a specialized vacuole (Westbroek et al., 1984), then extruded and incorporated into an extracellular coccosphere. Coccoliths are shed continuously, however, when the cell dies or lyses, large concentrations of coccoliths are detached and the surrounding water turns a characteristic milky white and it is during this period the bloom can be easily observed by satellite imagery. A vertical flux then follows as coccoliths sink to the seabed (Steinmetz, 1991; Ziveri et al., 2000). Consequently, high reflectance areas of any bloom are likely to be comprised of dead or dying E. huxleyi cells and the aim of this study was to determine if viruses are the cause of death.

Comparison of biological parameters, determined by analytical flow cytometry (AFG), between data collected outside and inside the high reflectance area led us to conclude that viruses were indeed responsible for the collapse of this bloom. Although such conclusions from similar data sets are not new (Bratbak et al., 1993, 1996; Brussaard et al., 1996; Castberg et al., 2001), there have been no reports of $E$. huxleyi-specific viruses being isolated and maintained in culture from E. huxleyi blooms. Bratbak et al. (1996) reported the initial isolation of a virus by plaque assay, however they were unable to propagate it further for characterization.

\section{Transect data}

Contour plots of transect data revealed very obvious differences between Station 1, outside and Stations 2-4, inside the high reflectance area (Figures 2-4). Briefly summarized: inside the high reflectance area concentrations of viruses were higher (Figure 2); E. huxleyi cells were lower (Figure 4A); coccoliths were higher (Figure 4B); bacteria were higher (Figure $3 \mathrm{~B}$ ) and virus to bacteria ratio (VBR) was lower (Figure 3A) than at Station 1, outside the high reflectance area. These data can simply be interpreted as virus-induced lysis of E. huxleyi cells in the bloom causing large concentrations of coccoliths to detach resulting in the high reflectance observed by satellite imagery (Figure 1). This interpretation is supported by TEM images of fixed samples from inside the high reflectance area where large virus-like particles (LVLP) ranging from $120 \mathrm{~nm}$ to $200 \mathrm{~nm}$ in size were clearly abundant (e.g. Figure 5A). In addition, LVLPs were observed bursting from E. huxleyi cells (Figure 5B) suggesting that viruses were being actively propagated inside the high reflectance area.

Virus concentrations in this study are at least an order of magnitude higher than those measured in a developing
E. huxleyi bloom in the northern North Sea only one month earlier (Wilson et al., in press). These workers suggested that microzooplankton grazing contributed more significantly than viruses to $E$. huxleyi loss processes during the developing stages of a bloom, particularly since Archer et al. (2001) calculated that grazing accounted for between $22 \%-39 \%$ of $E$. huxleyi turnover in that same bloom. During a parallel study in the Plymouth bloom, Fileman et al. (2002) demonstrated that protozoan abundances were higher in the high reflectance area than Station 1. Moreover, these workers calculated that microzooplankton accounted for $61 \%-64 \%$ of total phytoplankton community turnover in the high reflectance area. However, more significantly, Fileman et al. (2002) revealed that pigment-specific grazing rates on prymnesiophytes was actually low and dinoflagellates and cryptophytes formed a more important food source for the microzooplankton grazers in their parallel study. This further supports the prediction made by Wilson et al. (in press) who discussed that viruses would play a much more important role towards the end of a bloom when virus concentrations would reach a threshold level required to cause termination of that bloom. Indeed, numerous mesocosm studies have been conducted where high concentrations of LVLPs have been observed following the demise of the E. huxleyi population (Bratbak et al., 1993; Wilson et al., 1998; Castberg et al., 2001). It is difficult to measure such termination at sea since it is not often logistically possible to be on a ship throughout the progression of a bloom. The transect conducted on 30 July 1999 was probably the equivalent of the latter stages (Station 1) and termination (Stations 2-4) of an E. huxleyi bloom. The bloom had been tracked in the South West approaches of the English Channel by the Plymouth Marine Laboratory Remote Sensing Data Analysis Service (RSDAS http:// www.npm.ac.uk/rsdas/) from the end of June 1999 and both the high reflectance and high chlorophyll areas had disappeared by 14 August (data not shown).

Since the concentration of LVLPs was significantly higher in Stations 2-4 (Figure 2B), it was assumed the majority of them were derived from lysing $E$. huxleyi cells. If the burst size of infected $E$. huxleyi is $>300$, as Figure 5B suggests, then this is not an unreasonable assumption to make. Indeed, other algal viruses have been shown to have very large burst sizes of up to 4100 (Sandaa et al., 2001). Unfortunately, one of the drawbacks of AFG is that it is difficult to prove that separate clusters identified on AFG scatter plots can be attributed to specific virus groups, therefore we can only make assumptions on the likely hosts from viruses detected in natural samples.

Surface chlorophyll concentrations inferred from satellite imagery (ranging from $1.4 \mathrm{gl}^{-1}$ at Station 1 to 2-7.5 $\mathrm{g} \mathrm{l}^{-1}$ at Stations 2-4: data not shown), taxonomy data (Fileman et al., 2002) and AFG analysis revealed that a bloom was still occurring in the high reflectance area. It had switched from E. huxleyi domination (Station 1) to a mixture of autotrophic dinoflagellates $(<50 \mu \mathrm{m})$, nanophytoplankton, cryptophytes and picoeukaryotes, whose concentrations were all higher inside the high reflectance area suggesting that virus-induced $E$. huxleyi lysis had triggered a rapid succession of the phytoplankton community. Castberg et al. (2001) reached a similar conclusion using 
molecular methods (denaturing gradient gel electrophoresis) where they demonstrated that a new eukaryote community developed following the virus-induced demise of an E. huxleyi bloom during a seawater mesocosm experiment. It is worth noting that viruses that infect all these different phytoplankton strains would probably have a similar AFG signature to $E$. huxleyi-specific viruses, though this has not been rigorously examined.

Following E. huxleyi cell lysis, high concentrations of organic matter would be released, hence contributing to an increase in bacteria concentrations inside the high reflectance bloom (Figure 3B). Concurrently, the virus to bacteria ratio (VBR) decreased from an average of 33.0 $( \pm 5.2)$ outside the bloom to an average of $13.9( \pm 5.9)$ at Stations 2-4 (Figure 3A). Despite these VBRs being higher than usual they are still within the range expected for productive open water systems (Wommack \& Colwell, 2000). Wilson et al. (in press) demonstrated that a drop in VBR between different thermal layers in an E. huxleyi bloom in the North Sea, correlated with an increase in bacteria production. Hence, it is likely that the increase in bacteria concentrations observed in the current study (Figure 3B) is indicative of increased bacteria production responding to a flux of organic matter caused by E. huxleyi cell lysis. A similar increase in bacteria concentration was observed by Castberg et al. (2001) following the demise of an E. huxleyi bloom during a recent mesocosm study. In addition, these workers observed a dramatic change in bacteria community composition where there was an increase in bacteria diversity following the collapse of the E. huxleyi bloom. Similarly, Bratbak et al. (1998) demonstrated that bacteria production increased following algal virus lysis of Phaeocystis pouchetii cultures.

\section{Virus isolation}

The use of AFG and TEM can be criticized for not providing foolproof evidence for the presence of viruses. Usually Koch's postulates must be met before the presence of an infectious agent can be proved. Briefly, to fulfil Koch's postulates the infectious virus must be filterable, transferable and cause the same disease symptoms, following propagation, in a healthy host. The two virus strains isolated in this study, EhV84 and EhV86 (Figure 7) met these criteria. EhV84 was isolated from a water sample collected from a routine sampling trip four days before the main transect. Satellite imagery showed that EhV84 was also collected from a high reflectance area on 26 July 1999 (data not shown), unfortunately we do not have any further relevant data available for this day. The isolation of a second virus strain, $E h \mathrm{~V} 86$, from water collected inside the high reflectance area of the bloom during the transect, confirmed that viruses must have been involved in the demise of the E. huxleyi bloom, further supporting data collected during the transect.

Basic characterization revealed EhV 84 and EhV86 were lytic viruses (Figure 6) approximately $170 \mathrm{~nm}-190 \mathrm{~nm}$ in diameter with an icosahedral symmetry (Figure 7), similar to LVLPs observed in fixed samples collected from the bloom (Figure 5). The sulphurous odour observed following host cell lysis is likely to be caused by dimethyl sulphide, a potent climatically active biogenic gas. Emiliania huxleyi has high intracellular DMSP concentrations (Keller et al., 1989) and elevated DMS levels are found in blooms of this species (Malin et al., 1993; Matrai \& Keller, 1993). Previously, laboratory studies have also revealed that viral lysis of phytoplankton does significantly increase DMS/ DMSP release (Hill et al., 1998; Malin et al., 1998).

Characterization of EhV84 and EhV86 showed they are similar to other viruses that belong to the family Phycodnaviridae, a group of large double-stranded DNA viruses that infect aquatic algae (van Etten et al., 1991; van Etten \& Meints 1999). Indeed, EhV84 and EhV86 are further characterized by Schroeder et al. (in press) who demonstrated that they belong to the family Phycodnaviridae. These workers performed a phylogenetic analysis of the DNA polymerase gene, revealing that EhV84 and EhV86 actually belong to a new virus genus they propose to call the coccolithovirus. Similar sized E. huxleyi-specific viruses have also been isolated from coastal seawater off the coast of Bergen, Norway (Tonje Castberg, personal communication), suggesting that these viruses are widespread.

Taken together, transect and isolation data suggest that viruses were the major contributor to the demise of the E. huxleyi population in the high reflectance area off the coast of Plymouth in July 1999. It is likely there was close coupling between microalgae, bacteria and viruses that contributed to a large organic carbon input. Consequent cycling influenced the succession of an E. huxleyi-dominated population to a more characteristic mixed summer phytoplankton community. The isolation of E. huxleyispecific viruses confirmed the involvement of viruses in this succession. Further characterization of these viruses may help to further understand their ecological role, mechanism of infection and role in biogeochemical cycling.

This study was partly funded by M\&FMB (Marine and Freshwater Microbial Biodiversity) grant no. NER/T/S/2000/00640 awarded to W.H.W. and G.M. M\&FMB is a community programme funded by the Natural Environmental Research Council of the United Kingdom (NERC). It was also partly funded by the NERC through the Plymouth Marine Laboratory (PML) core strategic research programme Microbially Driven Biogeochemical Cycles (MDB). W.H.W. is a Marine Biological Association of the UK Research Fellow. Tim Smyth and Steve Groom, PML RSDAS are acknowledged for providing help and information on the satellite imagery. We also acknowledge the help of the skipper and crew of RV 'Squilla'.

\section{REFERENCES}

Archer, S.D., Widdicombe, G.E., Tarran, G.A., Rees, A.P. \& Burkill, P.H., 2001. Production and turnover of particulate dimethylsulphoniopropionate during a coccolithophore bloom in the northern North Sea. Aquatic Microbial Ecology, 24, 225-241.

Bergh, O., Børsheim, K.Y., Bratbak, G. \& Heldal, M., 1989. High abundance of viruses found in aquatic environments. Nature, London, 340, 467-468.

Børsheim, K.Y., Bratbak, G. \& Heldal, M., 1990. Enumeration and biomass estimation of planktonic bacteria and viruses by transmission electron-microscopy. Applied and Environmental Microbiology, 56, 352-356.

Bratbak, G., Egge, J.K. \& Heldal, M., 1993. Viral mortality of the marine alga Emiliania huxleyi (Haptophyceae) and termination of algal blooms. Marine Ecology Progress Series, 93, 39-48. 
Bratbak, G., Jacobsen, A. \& Heldal, M., 1998. Viral lysis of Phaeocystis pouchetii and bacterial secondary production. Aquatic Microbial Ecology, 16, 11-16.

Bratbak, G., Wilson, W. \& Heldal, M., 1996. Viral control of Emiliania huxleyi blooms? Fournal of Marine Systems, 9, 75-81.

Brussaard, C.P.D., Kempers, R.S., Kop, A.J., Riegman, R. \& Heldal, M., 1996. Virus-like particles in a summer bloom of Emiliania huxleyi in the North Sea. Aquatic Microbial Ecology, 10, 105-113.

Castberg, T. et al., 2001. Microbial population dynamics and diversity during a bloom of the marine coccolithophorid Emiliania huxleyi (Haptophyta). Marine Ecology Progress Series, 221, 39-46.

Charlson, R.J., Lovelock, J.E., Andreae, M.O. \& Warren, S.G., 1987. Oceanic phytoplankton, atmospheric sulfur, cloud albedo and climate. Nature, London, 326, 655-661.

Etten, J.L. van, Lane, L.C. \& Meints, R.H., 1991. Viruses and virus-like particles of eukaryotic algae. Microbiological Reviewes, 55, 586-620.

Etten, J.L. van \& Meints, R.H., 1999. Giant viruses infecting algae. Annual Review of Microbiology, 53, 447-494.

Fileman, E.S., Cummings, D.G. \& Llewellyn, C., 2002 Microplankton community structure and the impact of microzooplankton grazing during an Emiliania huxleyi bloom, off the Devon coast. Fournal of the Marine Biological Association of the United Kindom, 82, 359-368.

Fuhrman, J.A., 1999. Marine viruses and their biogeochemical and ecological effects. Nature, London, 399, 541-548.

Gordon, H.R. \& Du, T., 2001. Light scattering by nonspherical particles: application to coccoliths detached from Emiliania huxleyi. Limnology and Oceanography, 46, 1438-1454.

Guillard, R.R.L., 1975. Culture of phytoplankton for feeding marine invertebrates. In Culture of marine invertebrate animals (ed. W.L. Smith and M.H. Chanley), pp. 29-60. New York: Plenum Press.

Hill, R.W., White, B.A., Cottrell, M.T. \& Dacey, J.W.H., 1998. Virus-mediated total release of dimethylsulfoniopropionate from marine phytoplankton: a potential climate process. Aquatic Microbial Ecology, 14, 1-6.

Holligan, P.M. et al., 1993. A biogeochemical study of the coccolithophore, Emiliania huxleyi, in the North Atlantic. Global Biogeochemical Cycles, 7, 879-900.

Jacobsen, A., Bratbak, G. \& Heldal, M., 1996. Isolation and characterization of a virus infecting Phaeocystis pouchetii (Prymnesiophyceae). Fournal of Phycology, 32, 923-927.

Keller, M.D., Bellows, W.K. \& Guillard, R.R.L., 1989. Dimethyl sulfide production in marine phytoplankton. In Biogenic sulfur in the environment (ed. E.S. Saltzman and W.J. Cooper), pp. 183-200. American Chemical Society.

Malin, G., Liss, P.S. \& Turner, S.M., 1994. Dimethyl sulphide: production and atmospheric consequences. In The haptophyte algae, vol. 51 (ed. J.C. Green and B.S.C. Leadbeater), pp. 303-320. Oxford: Clarenden Press.

Malin, G., Turner, S., Liss, P., Holligan, P. \& Harbour, D., 1993. Dimethylsulfide and dimethylsulphoniopropionate in the northeast Atlantic during the summer coccolithophore bloom. Deep-Sea Research Part I-Oceanographic Research Papers, 40, 1487-1508.

Malin, G., Wilson, W.H., Bratbak, G., Liss, P.S. \& Mann, N.H., 1998. Elevated production of dimethylsulfide resulting from viral infection of cultures of Phaeocystis pouchetii. Limnology and Oceanography, 43, 1389-1393.
Marie, D., Brussaard, C.P.D., Thyrhaug, R., Bratbak, G. \& Vaulot, D., 1999. Enumeration of marine viruses in culture and natural samples by flow cytometry. Applied and Environmental Microbiology, 65, 45-52.

Matrai, P.A. \& Keller, M.D., 1993. Dimethylsulfide in a largescale coccolithophore bloom in the Gulf of Maine. Continental Shelf Research, 13, 831-843.

Nagasaki, K., Ando, M., Itakura, S., Imai, I. \& Ishida, Y., 1994. Viral mortality in the final stage of Heterosigma akashiwo (Raphidophyceae) red tide. Fournal of Plankton Research, 16, 1595-1599.

Nagasaki, K. \& Yamaguchi, M., 1997. Isolation of a virus infectious to the harmful bloom causing microalga Heterosigma akashiwo (Raphidophyceae). Aquatic Microbial Ecology, 13, 135-140.

Sandaa, R.A., Heldal, M., Castberg, T., Thyrhaug, R. \& Bratbak, G., 2001. Isolation and characterization of two viruses with large genome size infecting Chrysochromulina ericina (Prymnesiophyceae) and Pyramimonas orientalis (Prasinophyceae). Virology, 290, 272-280.

Schroeder, D., Oke, J., Malin, G. \& Wilson, W.H., in press. Coccolithovirus (Phycodnaviridae), characterisation of a new algal virus genus. Archives of Virology.

Steinmetz, J.C., 1991. Calcareous nanoplankton biocoenosis: sediment trap studies in the equatorial Atlantic, central Pacific and Panama Basin. In Ocean biocoenosis, Series no. 1 (ed. S. Honjo), pp. 1-85. Woods Hole, Massachusetts: Woods Hole Oceanographic Institution Press.

Westbroek, P. et al., 1993. A model system approach to biological climate forcing - the example of Emiliania huxleyi. Global and Planetary Change, 8, 27-46.

Westbroek, P., Dejong, E.W., Van der Wal, P., Borman, A.H., Devrind, J.P.M., Kok, D., Debruijn, W.C. \& Parker, S.B., 1984. Mechanism of calcification in the marine alga Emiliania huxleyi. Philosophical Transactions of the Royal Society B, 304, 435-444.

Westbroek, P., Van Hinte, J.E., Brummer, G.J., Veldhuis, M., Brownlee, C., Green, J.C., Harris, R. \& Heimdal, B.R., 1994. Emiliania huxleyi as a key to biosphere-geosphere interactions. In The haptophyte algae, vol. 51 (ed. J.C. Green and B.S.C. Leadbeater), pp. 321-334. Oxford: Clarendon Press.

Wilhelm, S.W. \& Suttle, C.A., 1999. Viruses and nutrient cycles in the sea-viruses play critical roles in the structure and function of aquatic food webs. Bioscience, 49, 781-788.

Wilson, W.H., Tarran, G.A. \& Zubkov, M.V., in press. Virus dynamics in a coccolithophore-dominated bloom in the North Sea. Deep Sea Research.

Wilson, W.H., Turner, S. \& Mann, N.H., 1998 Population dynamics of phytoplankton and viruses in a phosphatelimited mesocosm and their effect on DMSP and DMS production. Estuarine, Coastal and Shelf Science, 46, 49-59.

Wommack, K.E. \& Colwell, R.R., 2000 Virioplankton: viruses in aquatic ecosystems. Microbiology and Molecular Biology Revieres, 64, 69-114.

Ziveri, P., Broerse, A.T.C., Van Hinte, J.E., Westbroek, P. \& Honjo, S., 2000 The fate of coccoliths at 48 degrees N 21 degrees W, northeastern Atlantic. Deep-Sea Research Part IiTopical Studies in Oceanography, 47, 1853-1875.

Submitted 3 December 2001. Accepted 19 April 2002. 